2018 Global Marketing Conference at Tokyo Proceedings: 1114-1118 (July 2018)

https://doi.org/10.15444/GMC2018.09.05.04

\title{
CORPORATE SOCIAL RESPONSIBILITY INITIATIVES INFLUENCE CUSTOMER AWARENESS AND EMPOWERMENT
}

\author{
Sandra Maria Correia Loureiro, Instituto Universitário de Lisboa (ISCTE-IUL), Portugal \\ João Lopes, Instituto Universitário de Lisboa (ISCTE-IUL), Portugal ${ }^{2}$
}

\begin{abstract}
\section{Introduction}

The traditional approaches on corporate social responsibility communication are revealing to be unable of raising awareness and increasing stakeholders' empowerment, often failing to improve positive relationships with consumers. In this study, the digitally co-created CSR activities will be explored using a more general approach, which will also take into consideration these philanthropic activities, i.e. the activities where companies invite stakeholders to participate in the resolution of a social issue but without asking them to buy the brand's products.

Moreover, in the present study, interactivity and freedom of cause' choices are both believed to be two mechanisms that play a key role in generating more empowered stakeholders, with increased propensity for participating in co-created CSR initiatives. Therefore, it is important to analyse digitally co-created CSR activities since it may represent a major opportunity for organizations to add value and meaning to stakeholders (and even for society at large), where the two parties work together to solve a social issue.
\end{abstract}

\section{Theoretical development}

The World Business Council for Sustainable Development (WBCSD, 1999) defined Corporate Social Responsibility as the "continuing commitment by business to behave ethically and contribute to economic development while improving the quality of life of the workforce and their families as well as of the local community and society at large."

Although previous findings regarding the financial implications of CSR might have been ambiguous, there is an increasingly acceptance about the positive outcomes these activities have in building brand equity, brand image (Esmaeilpour \& Barjoei, 2016), in improving reputation, trust and loyalty among consumers (Stanaland et al., 2011) and in the willingness consumers have to purchase and possibly even paying higher prices for products of firms with more CSR engagement (Servaes \& Tamayo, 2013).

Additionally, with consumers' and other stakeholders' (e.g., employees, channel partners, regulators) increasing expectations that organizations should behave in socially responsible ways (Mishra \& Modi, 2016), CSR has become an integral part of business practice over the last years, with many firms dedicating a section of their annual reports and corporate websites to CSR activities (Servaes \& Tamayo, 2013).

Arrillaga-Andreessen (2016) notes that the new generations seem to have social consciousness embedded in their DNA. They are united in wanting to do more than acquire material riches and measure success by their ability to transform the lives of

\footnotetext{
${ }^{1}$ sandramloureiro@netcabo.pt

2 jp.g.lopes@hotmail.com
} 
others. Their question is not "What do I want to be when I grow up?" but "How will the world be different because I lived in it?".

In Euromonitor's Top 10 Global Consumer Trends for 2015, Consumer Trends Consultant Daphne Kasriel-Alexander states that consumption is increasingly being driven by the heart: consumers are making choices defined by their positive impact on the world and community.

Despite the strong interest in CSR activities, particularly in its outcomes, in firms' value and branding, there is yet little research and empirical studies regarding the effects of these activities in a social media context. This exploratory research aims to fill this gap, by focusing on the branding outcomes a CSR activity can generate while communicated in Social Networking Sites (SNS) and using participatory approaches.

Some researchers already found it questionable how stakeholder dialogue and engagement through corporate websites and CSR reports are accomplished and if they necessarily lead to greater stakeholder participation (Chaudhri, 2016). Thus, one of the research objectives is to examine if using a participatory CSR activity in social media rather than (or, at least, combined with) the traditional approach of communicating CSR performance on firms' annual reports can generate greater outcomes for brands, especially by testing if these activities can raise awareness, increase participation and empowerment levels.

Some authors ( $\mathrm{Du}$ et al., 2010) found two key challenges regarding CSR communication: the first one is the need for higher levels of awareness, as several researchers already found that a company can only benefit, enhance critical branding outcomes and even increase firm value through CSR activities if it has a high advertising intensity. These activities have low or negative impact on firm value for firms with low advertising intensity, sometimes with costs outweighing the benefits, as the lack of customer awareness about CSR activities represents a major limiting factor for their ability to respond to such activities (Servaes \& Tamayo, 2013). Thus, Sen et al. (2006) argue that to reap the positive benefits of CSR, companies need to work harder at raising awareness levels.

Although not every firm might experience high levels of awareness (since not every organization can support high advertisement intensity or already have strong branding), this research responds to the call for further research by "exploring channels available for dissemination of CSR activities" (Servaes \& Tamayo, 2013:1059), in particular, the social media channels, and by providing new research on "the extent to which these new social and communicative arrangements are being realized by organizations and stakeholders and the attendant implications for CSR communication", as it currently represents an "evolving area of investigation" (Chaudri, 2016, p.422).

Therefore, once it is recommended that companies work on increasing CSR awareness levels, social media sites, such as Facebook, can be powerful channels not only due to its popularity and vast audience reach at a much lower cost, but also due to the opportunities consumers' word-of-mouth can create (Du, Bhattacharya, \& Sen., 2010).

The second challenge is concerned with minimizing stakeholder scepticism. Stakeholders quickly become suspicious of the CSR motives when companies aggressively promote their CSR efforts (Du, Bhattacharya, \& Sen, 2010). Communicating CSR is a very delicate matter. It requires a certain sensitivity and balance, where organizations face the paradox of demonstrating social responsibility without communicating it blatantly, and being simultaneously credible, informative, and engaging (Chaudri, 2016). There's also no room for inconsistencies, as CSR is all 
about being selfless and charitable, the need for transparency and honesty is a must, since on one hand, these activities can have a backlash effect if stakeholders become suspicious and perceive predominantly extrinsic motives in companies' social initiatives (i.e. when the company is seen as attempting to increase its profits) and, on the other hand, stronger attributions to genuine concern are likely to be associated with more positive reactions towards the company, both internally and behaviourally (Sen et al., 2006). Kesavan et al. (2013) also found that social media is increasingly perceived by consumers as a more trustworthy source of CSR information than traditional media tools (e.g., TV and advertising). Based on above argumentation we formulate:

H1: Online co-created CSR activities have greater potential for raising awareness than the traditional communication channels.

H2: Online participatory CSR activities can increase consumers' empowerment levels.

\section{Research design}

Globally, the questionnaire is composed of 28 questions, separated into three sections. The first section is composed by 14 questions that measured social networking usage, current CSR awareness levels, general use of the traditional CSR communication channels, current level of control felt by respondents towards CSR activities, the empowerment felt after companies adding cause choice freedom and respondents' attitudes towards the effectiveness and outcomes of participatory CSR initiatives. The second section of the questionnaire consists in 10 questions regarding a real CSR initiative, implemented in March 2016, by one of the biggest Portuguese retailers Continente. After a brief contextualization, the questions measured activity recall rate, participation rate, reasons to (or not to) participate, WoM dissemination rate (or propensity), perception of brand image after the initiative and attitudes towards online co-created CSR initiatives (acceptance levels). The third and last section contained 4 questions regarding socio-demographic measures, namely: nationality, age, gender and educational level.

The launch of the questionnaire comprises two stages: for the first stage, it is prepared a pre-test of the questionnaire, which was the pillar for the second and main stage: the online questionnaire. Pre-testing is a method to evaluate in advance if a questionnaire causes misunderstandings, ambiguities, or other difficulties with instrument items to respondents, helping researchers minimizing future errors. During the pre-test stage, a total of 10 people is selected to be monitored while responding to the first draft of the questionnaire. This stage provided important insights about each one of the questions previously elaborated, allowing for reviewing and refining them, as well as adding more questions that revealed to be relevant for the study. As for the second stage, the online questionnaire was launched in social networks - Facebook, Instagram and LinkedIn - and in an international forum - Reddit, from $18^{\text {th }}$ of June of 2017 to $01^{\text {th }}$ of August of 2017.

\section{Results and conclusions}

Findings from 322 valid responses provide clear evidence that co-creating socially responsible activities in social media can indeed increase not only the awareness for such actions, but also increase empowerment, participation levels, positive word-ofmouth dissemination, and reinforce consumer-brand ties in the process.

Currently, individuals feel very low control regarding the process and the outcomes of CSR initiatives, and that by providing interactivity experiences and adding freedom of 
cause choice, organizations can increase stakeholders' empowerment levels, consequently enhancing participation, one of the dimensions of consumer engagement. Online users are starting to connect with their preferred brands in social media and are demanding interactive experiences. Although SNS presents many opportunities for brands to guarantee that they remain relevant to its consumers and other stakeholders, the findings imply that social media remains unexplored as a CSR communication channel by organizations. Considering that the traditional communicating channels used to inform shareholders about these initiatives have a very low adherence by the general public and that they are failing to provide more awareness to CSR activities, brand managers need to devise different strategies for the optimal communication of these initiatives in new channels, which have higher potential to result not only in improved attitudes and brand image, but also in the increased intent of stakeholders to commit personal resources (e.g., money, time, etc.) to the benefit of the company, in a near future. Even for the users who do not follow brands in their SNS, for example, companies can still use SNS tools such as targeted posts (i.e. promoted posts that appear in target users' feed), to ensure that their awareness and relevance levels remains significant, especially when companies are seeking for users with specific interests.

Keywords: corporate social responsibility; co-creation; social media; communication.

\section{References}

Chaudhri, V. (2016). Corporate Social Responsibility and the communication imperative: Perspectives from CSR managers. International Journal of Business Communication, 53(4), 419-442

Du, S., Bhattacharya, C.B. \& Sen, S. (2010). Maximizing Business Returns to Corporate Social Responsibility (CSR): The Role of CSR Communication. International Journal of Management Reviews, 12(1), 8-19

Esmaeilpour, M. \& Barjoei, S. (2016). The impact of Corporate Social Responsibility and image on brand equity. Global Business and Management Research: An International Journal, 8(3), 55-66.

Kasriel-Alexander, D. (2015). Top 10 global consumer trends for 2015. Euromonitor International

Kasriel-Alexander, D. (2016). Top 10 global consumer trends for 2016. Euromonitor International

Kesavan, R., Bernacchi, M. D. \& Mascarenhas, O. A. J. (20139. Word of Mouse: CSR Communication and the Social Media. International Management Review, 9(1), 59-67

Mishra, S. \& Modi, S. B. (2016). Corporate Social Responsibility and Shareholder Wealth: The Role of Marketing Capability. Journal of Marketing, 80(1), 26-46.

Sen, S., Bhattacharya, C. B. \& Korschun, D. (2006). The role of corporate social responsibility in strengthening multiple stakeholder relationships: a field experiment. Journal of the Academy of Marketing Science, 34(2), 158-166

Servaes, H. \& Tamayo, A. (2013). The Impact of Corporate Social Responsibility on Firm Value: The Role of Customer Awareness. Management Science, 59(5),1045-1061

Stanaland, A. J. S., Lwin, M. O. \& Murphy, P. E. (20119. Consumer Perceptions of the Antecedents and Consequences of Corporate Social Responsibility Journal of Business Ethics, 102,47-55 
World Business Council for Sustainable Development (WBCSD) (1999). Meeting changing expectations. Corporate Social Responsibility. New York: WBCSD 